about 528 microns. Thorax long and narrow, about 480 microns wide in middle; anterior legs about 704 microns behind head; anterior femora curved, convex above, concave below; their tibiæ rather short (about 288 microns), with a single long spur; their tarsi long, the first joint longer than next three together, and strongly curved; hind femora extremely broad and flattened, the summit of the curve about half-way between base and middle; abdomen with a rather long petiole.

Burmese amber, from R. C. J. Swinhoe. In the same slab as the type of Cryphalites rugosissimus, and $24.5 \mathrm{~mm}$. from it. Related to Scleroderma (?) quadridentatum, which may possibly belong to Apenesia, but on account of the black abdomen and various structural characters surely not its male.

\title{
DISTRIBUTIONAL NOTES ON NEW ENGLAND ODONATA.
}

$$
\text { PART I. }
$$

By R. Heber Howe, Jr., Thoreau Museum, Concord, Massachusetts.

Since Dr. P. P. Calvert's List was published in October, 1905, the following published corrections and additions have been made:

Argia apicalis (Say) Selys recorded from Maine by Dr. Calvert on the authority of Prof. Harvey was expunged by Dr. Calvert following an examination of the Harvey specimens by Mr. Williamson (Ent. News 17: 31. 1906). Argia moesta putrida (Hagen) was shown by Mr. E. B. Williamson to be synonymous with Argia mosta Hagen (Ent. News 23: 200. 1912.)

In Dr. E. M. Walker's “The North American Dragon-flies of the Genus Eshna (Univ. Toronto Studies, Biol. Series, 1912) the following New England records for the genus were made:

Aeshna corrulea septentrionalis Burm.

N. H. White Mts. (Scudder)

Eshna juncea Linn.

N. H. White Mts. (Scudder) 
. 140. AEshna interrupta Walker. New species for New England

Me. Portland (Jones)

Vt. $($ Frost $)$

Mass. - (Uhler)

141. Eshna eremita Scudd. New species for New England

Me. Six Ponds, Piscataquis Co. (Harvey)

N. H. Franconia (Slosson)

Hermit Lake, Mt. Washington (Scudder)

Eshna clepsydra Say

Me. Manchester (Wadsworth)

Mass. Brookline (Shurtleff)

Provincetown (Benedict)

Wilbrahim (Hagen)

Boston (Uhler)

Salem (True)

Natick (Sanborn)

142. Eshna canadensis Walker. New species for New England

Me. Bradley (Harvey)

Manchester (Wadsworth)

Norway (Smith)

Orono (Harvey)

N. H. White Mts. (Shurtleff)

White Mts. House (Calvert)

Franconia (Calvert)

Fabyans

Vt. Newport (Slosson)

Mass. - (Needham)

Ashna verticalis Hagan $=A$. juncea verticalis (Hagen) of

Dr. Calvert's List

Me. Manchester (Wadsworth)

West Beach (Hagen)

Mass. Beverly

Cambridge

Nahant (Moring)

Salem (Lane)

Saugus

Sherbourne

Walpole (Sprague)

Westborn (Needham)

Wollaston (Sprague) 
143. Ashna tuberculifera Walker

Me. Islesboro (Dixon)

Manchester (Wadsworth)

Mass. Walpole (Sprague)

Essex Co., (Hagen)

Provincetown (Benedict)

Hampden (Needham)

Westborn (Needham)

144. Ashna umbrosa Walker

Me. Manchester (Wadsworth)

Augusta (Wadsworth)

Norway (Smith)

Gorham

Millinocket (Harvey)

Russell Stream (Corry)

Bradley (Harvey)

Greenfield (Harvey)

Six Ponds (Harvey)

N. H. Franconia (Slosson)

White Mts. (Sprague)

Hermit Lake (Scudder)

Centre Harbor

Mass. Boston

Cambridge

Amherst (Needham)

Wilbrahim (Martin)

Auburndale

Gor Head = Gay Head

Zshna constricta Say

Me. Manchester (Wadsworth)

Mass. Hampden (Needham)

145. Eshna mutata Hagen

Mass. Wilbrahim (Needham)

In the Proceedings of the Thoreau Museum of Natural History, I: 41, 1915, Mr. E. L. Peirson recorded the capture of the following species in Concord, Mass., and Dr. Calvert in the Ent. News, 26: 238-239, 1915 again noted Mr. Peirson's capture and added a record of a female taken by Mr. C. W. Johnson at Dedham, Mass. 
Mr. E. J. Smith of Sherborn, Mass., kindly permits me to here record the capture of a male, on April 30, 1913, at Sherborn.

146. Williamsonia lintneri (Hagen) Davis

Mass. Concord (Peirson)

Dedham (Calvert)

In Psyche, 23: 12-15, 1916, the author recorded AEeshna umbrosa and Eshna canadensis as new to New England having overlooked Dr. Walker's records. Libellula luctuosa Burm., though not uncommon, was added to Dr. Calvert's List.

147. Libellula luctuosa Burm.

Mass. Concord (Howe)

I now wish to record records of a few species sent me from Brandon, Vt., by Mr. D. Lewis Dutton; a small lot from North Guilford, Conn., sent by Mr. Geo. L. Howe; two species from Cataumet, Mass., sent by Miss Theresa Winsor; a summer's catch in New Hampshire made with the continual aid and co-operation of Mr. David M. Little, and a spring and autumn catch at Concord, Mass., made with the help of my daughter, Miss Susan A. Howe, and the Misses Shaw.

Anax junius (Drury) Selys. May 27, 1912. New to Vermont

Ashna eremita Scudd. Aug. 31, 1915. New to Vermont Eshna umbrosa Walker. May 6, 1915. New to Vermont Basiceshna janata (Say) Selys. May 22, 1912. New to Vermont

Plathemis lydia (Drury) Hagen. July, 1912. New to Vermont

Sympetrum rubicundulum (or var. obtrusum), teneral female. July, 1912, in either case new to Vermont

On September 18, 1915, I collected at Bristol and Middletown, R. I., and again at Middletown on June 3, 1916, and at Bristol on October 2, 1916. The following species were taken:

Lestes rectangularis Say. Bristol, Sept.

Enallagma civile (Hagen) Selys. Both stations, Sept.

Ischnura ramburii Selys. Both stations, Sept., Oct. 2 Anax junius (Drury) Selys. Middletown, Sept. 
Eshna tuberculifera Walker. Bristol, Sept. New to Rhode Island

Libellula pulchella Drury, Middletown, Sept.

Plathemis lydia (Drury) Hagen. Bristol, Sept.

Pantala flavescens (Fab.) Hagen, teneral. Bristol, Sept. New to Rhode Island

Sympetrum rubicundulum (Say) Kirby. Both stations, Sept.

Ischnura posita (Hagen) Needham. Middletown, Sept. and June

The collection from North Guilford, Conn., contained the following:

148. Celithemis monomelana Will. July, 1916. New to New England

Plathemis lydia (Drury) Hagen. July, 1916

The two species from Cataumet, Mass., were:

Erythrodiplax berenice (Drury) Ris. July, 1916

Epicordulia princeps (Hagen) Selys. July, 1916

I began collecting on Meredith Neck, N. H., on June 29 and visi ited various collecting grounds on the shores of Lake Winnepesaukee until August 23. These included Centre Harbor, Meredith, Moultonboro (Sanborn's Meadows), and made two trips to Lake Asquam, with one excursion to Newfound and one to Profile Lake. The list of species follows:

Agrion maculata Beauv. Meredith Neck, July 27. New to New Hampshire

Lestes disjunctus Selys. Meredith Neck and Moultonboro, Aug. 1-22

Lestes rectangularis Say. Meredith Neck, July 18-Aug. 15 Lestes vigilax Hagen. Meredith Neck and Moultonboro, July 6-Aug. 15. New to New Hampshire

Lestes inequalis Walsh. Meredith Neck and Moultonboro, July 6-Aug. 15

Argia mœsta Hagen. Meredith Neck and Moultonboro, July 7-Aug. 23. New to New Hampshire Argia violacea (Hagen) Selys. Meredith Neck, July 17Aug. 23. New to New Hampshire 
Nehalennia irene (Hagen) Selys. Meredith, July 5-24 and Moultonboro

Enallagma calverti Morse. Profile Lake, Aug. 12. New to New Hampshire

Enallagma hageni (Walsh) Selys. Meredith and Moultonboro, July 2-11. New to New Hampshire

Enallagma ebrium (Hagen) Selys. Meredith Neck and Moultonboro, July 5-18

Enallagma civile (Hagen) Selys. Lake Asquam, Moultonboro and Meredith Neck, July 23 to Aug. 14. New to New Hampshire

Enallagma minusculum Morse. Meredith Neck, Aug. 6-23. New to New Hampshire

Enallagma traviatum Selys. Moultonboro, July 18. One female. New to New Hampshire

Enallagma exsulans (Hagen) Selys. Meredith Neck, July 17-Aug. 7. New to New Hampshire

Enallagma signatum (Hagen) Selys. Meredith Neck and Moultonboro, July 2-Aug. 22. New to New Hampshire

Enallagma pollutum (Hagen) Selys. Moultonboro, July 2. New to New Hampshire

Ischnura verticalis (Say) Selys. Meredith Neck, Centre Harbor, Moultonboro, July 5-Aug. 22

Hagenius brevistylus Selys. Meredith Neck and Moultonboro, July 12-Aug. 22

Gomphus exilis Selys. Meredith Neck and Moultonboro, June 30-Aug. 2

Dromogomphus spinosus Selys. Meredith Neck, Newfound Lake, Moultonboro, July 20-Aug. 14

Anax junius (Drury) Selys. Meredith, July 5-27

AEshna verticalis (Hagen). Meredith Neck, Aug. 7-18

Eshna clepsydra Say. Moultonboro, Aug. 14-27

Eshna canadensis Walker. Moultonboro, Meredith Neck, Jackson, Aug. 2-22

Ashna eremita Scudd. Profile Lake and Moultonboro, Aug. 12-14

Eshna umbrosa Walker. Meredith Neck, Aug. 7-18 
149. Nasiceshna pentacantha Ramb. Moultonboro, July 9. New to New England

Basiceshna janata (Say) Selys. Meredith Neck, July 5-7 Boyeria vinosa (Say) McLachlan. Meredith Neck, July 25-Aug. 18. New to New Hampshire

Didymops transversa (Say) Hagen. Meredith Neck, July 11 Macromia illionoiensis Walsh. Meredith Neck and Moultonboro, Aug. 2-7

Neurocordulia obsoleta (Say) Selys. Meredith Neck, July 27-29. Crepuscular in habit

Epicordulia princeps (Hagen) Selys. Concord and Meredith Neck, June 29-Aug. 2. New to New Hampshire

Tetragoneuria cynosura simulans Mutt. $=T$. c. semiaquea (Burm) of Dr. Calvert's List. Meredith Neck and Moultonboro, July 2-20

Tetragoneuria spinigera (Selys) Selys. Meredith Neck, June 29-July 11

150. Tetragoneuria morio Mutt. Meredith Neck, June 29. New to New England

Somatochlora elongata (Scudd.) Selys. Centre Harbor and Jackson, July 14-Aug. 12

151. Somatachlora williamsoni Walker. Meredith Neck, July 17. New to New England

Cordulia shurtleffi Scudd. Moultonboro, July 8-18

Dorocordulia libera (Selys) Need. Moultonboro, July 8

Libellula exusta Say. Moultonboro and Meredith Neck, July 6-25

Libellula pulchella Drury. Centre Harbor, Meredith Neck, Moultonboro, July 5-Aug. 20

Libellula quadrimaculata Linn. Meredith Neck, Moultonboro, Centre Harbor, June 30-July 18

Plathemis lydia (Drury) Hagen. Centre Harbor, July 7 Sympetrum rubicundulum (Say) Kirby. Meredith Neck,

Centre Harbor, Moultonboro, Profile Lake, July 11Aug. 23

Sympetrum rubicundulum obtrusum (Hagen). Meredith Neck and Centre Harbor, July 5-7

Sympetrum vicinum (Hagen) Kirby. Meredith Neck and Jackson, Aug. 12-14 
Leucorhinia frigida Hagen. Moultonboro, July 6-Aug. 14 Leucorhinia glacialis Hagen. Moultonboro, July 6-9

Leucorhinia intacta (Hagen) Hagen. Meredith Neck, and Moultonboro, Centre Harbor, June 30-July 27

Celithemis elisa (Hagen) Walsh. Moultonboro, July 18Aug. 14. This species was also captured at Tyngsboro, Mass., on June 29.

I began collecting in Concord, Mass., with the first appearance of dragon-fly life and collected until June 28. On August 24 I returned from New Hampshire and collected until the end of the season. During these periods I added the following species to my Preliminary List published in Psyche (ibid.), bringing the number from 52 to 67.

Lestes uncatus Kirby. Common, June 27

152. (?) Argia sedula Hagen. Two specimens taken on June 2 were of doubtful determination by Mr. Williamson. The species would be new to New England.

Ischnura posita (Hagen) Need. Male, Sept. 3

Cordulegaster diastalops Selys. One female, June 1

Cordulegaster maculatus Selys. One male, June 28

AEshna tuberculifera Walker. One male, Sept. 3-6

ZEshna verticalis Hagen. Not uncommon, Aug. 15-Oct. 1 Epicordulia princeps (Hagen) Selys. Two males, June 23, July 28

Boyeria vinosa (Say) MacLachlan. One seen Sept. 13

Tetragoneuria cynosura var.simulans Mutt. Several, June 23

Helocordulia uhleri (Selys) Need. One male, May 29

Cordulia shurtleffi scudd. One female, June 27. New to Massachusetts

Libellula semifasciata Burm., teneral. June 23

Sympetrum rubicundulum var. obtrusum (Hagen). Male, Oct. 5

Leucorhinia intacta (Hagen) Hagen. Not uncommon, May 30-June 28

Through the kindness of Mr. C. W. Johnson, Curator, I have examined the collection of Odonata in the Boston Society of Natural History, and can add the following new records: 
Agrion maculata Beauv. New to Connecticut, Rowayton, and Rhode Island, Apponaug

Lestes uncatus Kirby. New to Connecticut, Darien

Lestes inequalis Walsh. New to Massachusetts, Cohasset, Blue Hills, No. Reading, Manomet

Gomphus parvulus (Selys) Need. New to Massachusetts, No. Reading and East Walpole

Cordulegaster maculatus Selys. New to Vermont, Bennington

Libellula semifasciata Burm. New to Connecticut, Darien

Erythrodiplax berenice (Drury) Ris. New to Connecticut, Rowayton

Tramea carolina (L.) Hagen. New to Connecticut, Darien 153. Tramea lacerata Hagen. New to New England, Chelsea, Mass., Sept. 6, 1868, female

Pachydiplax longipennis (Burm.) Brauer. New to Connecticut, Darien

All my determinations for the above species have been verified by either Messrs. Ed. B. Williamson, R. A. Muttkowski or E. M Walker, and to these gentlemen I extend my most hearty thanks.

\section{CYCLOLEPPTERON THEOBALD (DIPTERA: CULICIDAE).}

Some new, $i . e$. hitherto unreported localities for the group of Anophelines which Mr. Theobald placed together under the genus Cycloleppteron are: San Juan, Jajuga, Carolina, and Coamo Springs, Porto Rico, from which places specimens were sent by Dr. B. H. Dutcher, Lieut.-Colonel, Medical Corps, U. S. Army, during the period Sept. 11, 1914-July 15, 1915, since which time no collections from Porto Rico have been received.

C. S. LudLow.

Army Medical Museum,

Washington, D. C.,

January $30,191 \%$. 

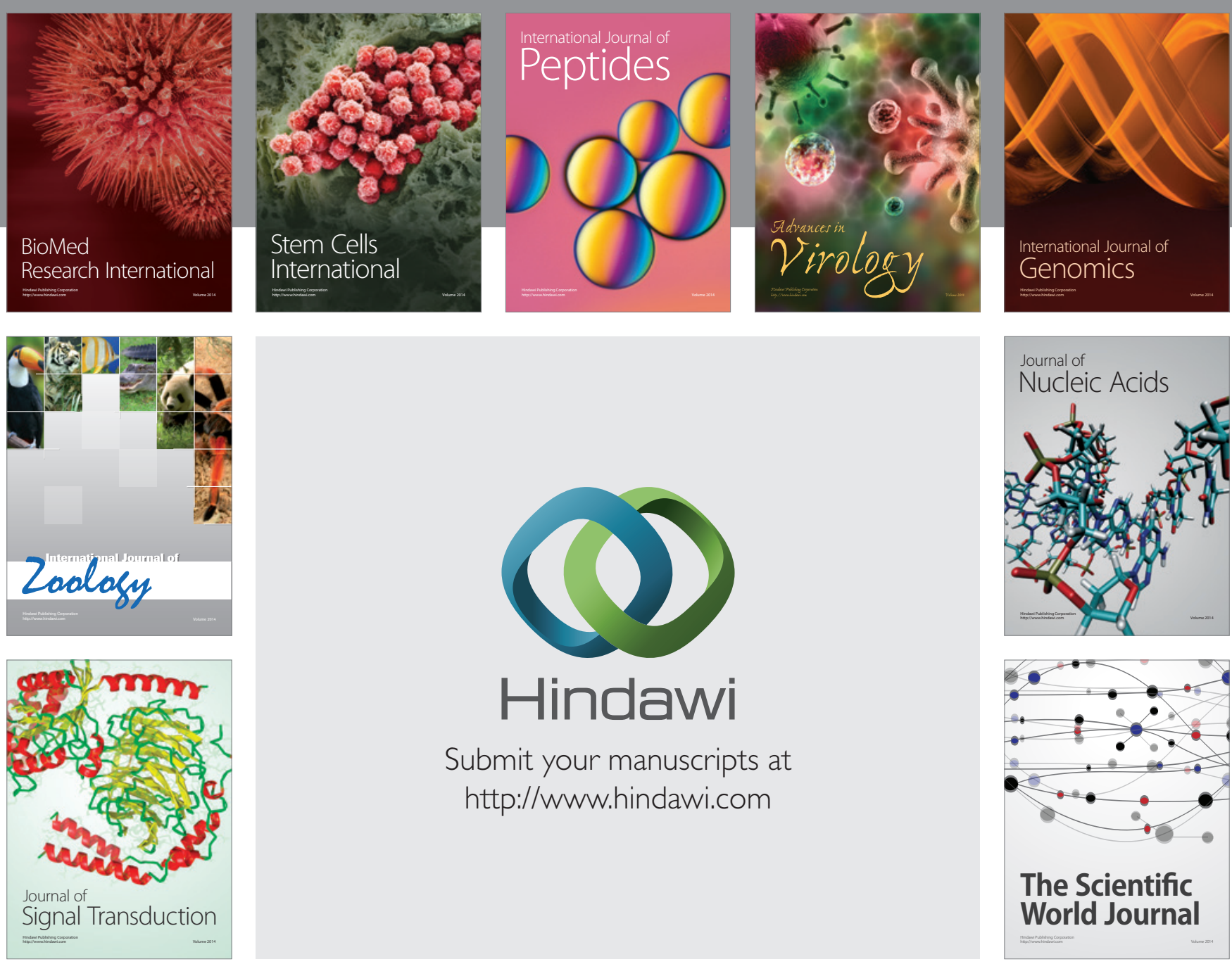

Submit your manuscripts at

http://www.hindawi.com
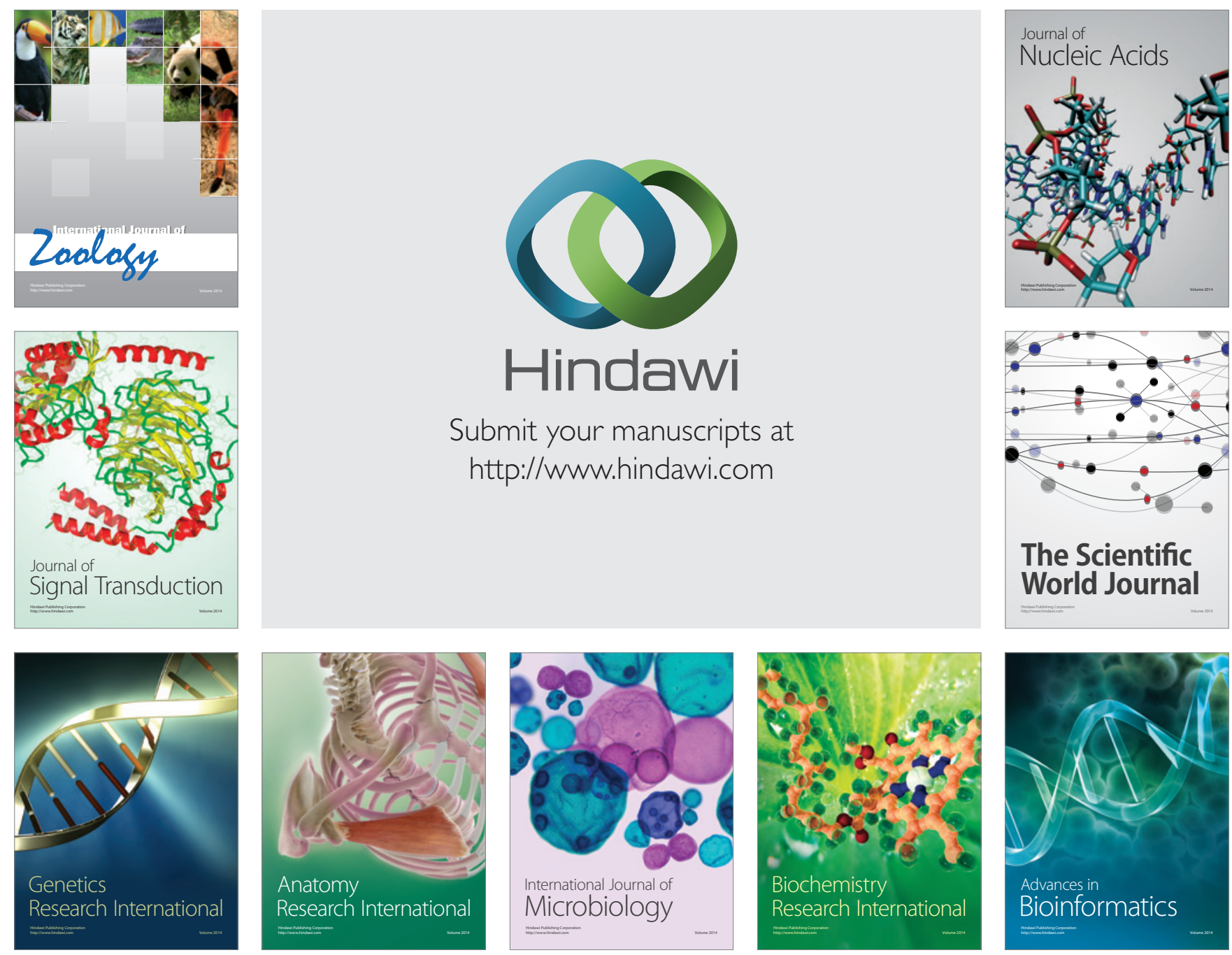

The Scientific World Journal
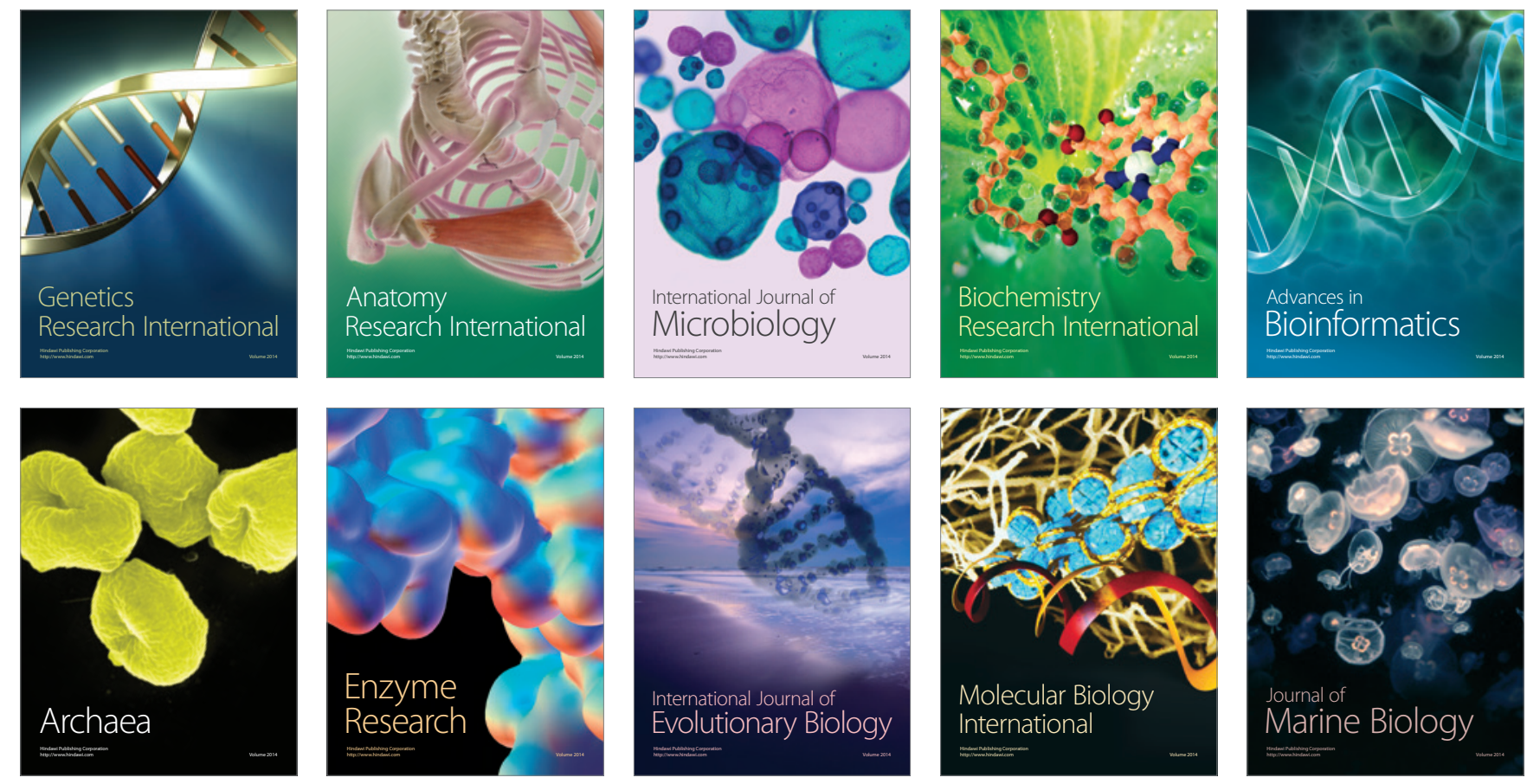